\title{
Family as the most important social institute of modern society
}

\author{
Ashurova Sarvinoz Uralovna, teacher at Qarshi state University
}

http://dx.doi.org/10.26739/2573-5616-2017-7-7-3

Abstract: The article reveals various aspects of the family as a central social institution of modern society, analyzed the functions of the family, the paradigm of the family crisis, the role of education in the life of the institution.

Key words: family, family functions, family crisis, family education, interpersonal relations, family and society.

\section{Семья как важнейший социальный институт современного общества}

Аннотация: В статье раскрываются различные аспекты семьи как основного социального института современного общества, анализируются функции семьи, парадигма семейного кризиса, роль воспитания в жизни данного института.

Ключевые слова: семья, семейные функции, семейный кризис, семейное воспитание, межличностные отношения, семья и общество.

\section{Семья как важнейший социальный институт современного общества}

Аннотация: мақолада оиланинг замонавий жамиятдаги асосий ижтимоий институт сифатидаги турли жихатлари очиб берилади, оила функциялари, оила зиддияти парадигмаси, мазкур институт хаётида тарбиянинг ахамияти тахлил қилинади.

Калит сўзлар: оила, оила функциялари, оилавий зиддият, оила тарбияси, шахслараро муносабатлар, оила ва жамият. 
The urgency of the problems of the family remains invariably acute throughout the development of psychological science and practice, since the questions concerning the existence of the family institution in society have always been most significant. Today, the problems caused by instability and unhappy families are more urgent for our society than ever before.

The family is the leading social institution, the most important factor in the formation of the personality. This means a historically established concrete system of relationships between spouses, parents and children, social necessity, which is conditioned by the need of society in the physiological and spiritual and reproduction of the population. The family is also a socio-psychological community - a small group, whose members are connected by marriage or kinship relations, commonality of life and mutual moral responsibility.

Let's consider the family as a social institution. Modern researchers distinguish four main characteristics of the family: a small social group; an important form of organization of personal life; a social institution based on a marriage (conjugal) union; multilateral relations of spouses with relatives.

The family can be defined as a community based on both marriage and blood relationship. This is the union of people, connected, as arule, with a commonality of life, as well as mutual responsibility and mutual assistance.

According to traditional ideas about a typical family, the basis or core of the latter is marriage. The institution of marriage regulates relations between spouses through norms and sanctions.

Marriage is a historically changing social form of relations between the sexes, through which society regulates and authorizes sexual life and establishes parental rights and duties.

The family, therefore, is a more complex entity than just a marriage group. The family is seen as a social institution, defined by a system of connections and relationships of individuals, with a stable structured organization that exerts a significant influence on the social structure of society, the reproduction of the population and the socialization of new generations[1].

\section{When characterizing the institution of the family, its functions should be indicated:}

At the same time, it is believed that the family - this is the tried and tested social institution, which is only, engaged in that way, which transfers all the valuable from social experience that has been accumulated by previous 
generations. With this, you can and should agree. But, on the other hand, in fulfilling its function of transferring social experience, the institution of the family is not limited to only those experiences that are acceptable from the point of view of the interests of society. The family, as a social institution, performs the function of accumulating all social experience, including what cannot be called socially necessary from the point of view of tomorrow; it also performs a selective function - selecting, absorbing, and reprocessing this experience, proceeding from the interests and needs of specific people[2].

In addition, the family fulfills the function of adapting the social experience accumulated by previous generations in the new conditions. On the other hand, such habits as alcohol abuse, smoking, other negative habits, lack of physical culture, immorality, as studies show, in many ways it is within the family that they form the basis of the system of value orientations of people.

From the point of view of hierarchy, prestige, the structures of power in the family are distinguished: traditional (with such historical types as patriarchal and matriarchal) and modern.

Along with the structure of kinship and the structure of power in the family, the structure of communications and the role structure are distinguished.

The well-known scientist A.G. Kharchev distinguished the following main functions of the family[3]:

- Reproductive (biological reproduction of the population in the public plan and satisfaction of the need for children - in the personal);

- Educational (socialization of the younger generation, maintenance of the continuity of culture in society);

- Economic and household (maintaining the physical health of members of society);

- Spiritual communication (development of personal qualities of family members);

- Social-status (reproduction of social structure);

- Economic (the receipt of material assets by some members of the family from others);

- The sphere of primary social control (regulation of the behavior of family members in various spheres of life);

- Leisure (organization of joint recreation);

- Emotional (getting mental protection and support);

- Sexual (sexual control, satisfaction of sexual needs). 
The most important functions of the family are status and protective functions.

Every person brought up in the family receives some statuses that are close to the statuses of members of his family. This, above all, refers to such important for the individual status as nationality, place in urban or rural culture, etc. In class societies, the family's belonging to a particular social stratum provides the child with the opportunities and rewards that are characteristic of this layer, and in the overwhelming majority of cases determine his future life. Of course, class status can change due to human efforts and favorable circumstances, but the beginning of the future must be sought in the family of this person. The family must necessarily carry out the role-playing of the child for the statuses close to the statuses of his parents and relatives, instilling in him the relevant interests, values and way of life.

In all societies, the institution of the family carries out to a different degree the physical, economic and psychological protection of its members. We are used to the fact that by touching the interests and security of any person, we also touch his family, whose members are defending their loved one or taking revenge for him. In most cases, all members of his family share guilt or shame for a person.

The functions of the family are historical and connected with the socioeconomic conditions in society, so over time, both the nature of the functions and their hierarchy change[4].

In the field of studying the sociology of the family are the living conditions of the family, its way of life, family ideology and the problems of the success of marriage and family relations, the stages of the life cycle of the family.

The development of the family, its types depend not only on the economy of society, but also on the social structure. The family largely depends on the general state of the spiritual life of society.

There are many different predictions about the future of family-marriage relations. In assessing individual aspects, some authors suddenly begin to assure that in the 21st century single individuals, single-parent families and divorces will disappear, although there are no grounds for such assumptions yet. Regarding the general trends of family development, serious researchers do not risk looking into the distant future because of the limited statistical material. But there is an opinion that the main direction of the development of the family is the evolution of it into a new, to some extent already existing, formally called a married couple. 
One of the first, who, at the beginning of the century, predictably predicted the likelihood of such development of family-marriage relations, was an outstanding Russian sociologist P. Sorokin. He wrote in 1916: "The future family will and can only be a free union of equal personalities"[5].

In the 60-ies of the twentieth century in English-speaking sociology, the idea of the development of most family systems to a matrimonial form was established. The range of motives for marriage is very wide: love, common interests and views, a sense of loneliness, the probability of a child's birth, the material security of the future spouse, the presence of an apartment, etc. Some researchers conditionally reduce the motivation of marriage to three subgroups: marriage for love, marriage for stereotypes of behavior, i.e., for the reflex of imitation, and marriage by calculation. Others talk about five types of motivation: for love, for spiritual intimacy, for material calculation, for psychological adequacy, for moral reasons. Of course, different combinations of motifs are possible [6].

In developed countries, the idea of the family's self-worth, the importance of normal interpersonal relationships is gradually asserted.

One cannot fail to mention that one of the scientific directions in the sociology of the family - the paradigm of the crisis of the family as a social institution - gives grounds for gloomy forecasts about the prospects of the family. There is an opinion that its social potential has been exhausted. Indeed, the statistics of recent years record an increase in the number of marriages being concluded, but the number of divorces continues to increase in parallel, which accordingly increases the number of incomplete, so-called fragment families (parent plus child).

Assessing the prospects for the functioning of the social institution of the family, two important aspects of the problem, in our opinion, are important: first, the ability of the family to fulfill the functions assigned to it aimed at meeting the needs of society; secondly, the functions of the family in the future, in accordance with the changing needs of society. For example, the need for reproduction, so relevant today, may lose its significance - it is possible that in the near future mankind will learn how to produce themselves and without the participation of the family.

Currently in Western society, the family institute is experiencing a real crisis. This is manifested in a decrease in the prestige of the family, in the increase in the number of divorces and incomplete families, in the increasingly frequent birth of children outside marriage, in the unwillingness of young people to create families and start children, in a constant decline 
in the birth rate, and in the increase in infant mortality. Often, the family is not the primary reference person for the person whom it is called upon to be. In this regard, the family does not cope with its tasks; its functional potential is decreasing. Therefore, today the concept of "dysfunctional family" has become relevant. The destruction of the traditions of the family is one of the causes of the crisis in the spiritual, moral and sociocultural sphere of modern society. The deterioration of the socio-demographic situation translates the problem of the family from the social, into the economic and psychological plane. It is no accident that family policy becomes a priority direction of the state policy of many countries

Among the values created by mankind for millennia, the family is one of the not passing. No nation, no people could do without a family. Any state regards the family as an important component of society. It is during the crisis that the role of the family and importance as an important buffer between the individual and social changes increase. Being one of the oldest institutions of society, the family in one form or another managed to survive in the conditions of all known historical civilizations and cultures. It has proved to be a very functional system with a high ability to adapt in a wide variety of environments.

The fate of the people is being decided in the family. It cultivates loyalty to traditions, love for one's native language, and reverence for the spiritual and moral treasures of the native people. The national Diaspora keeps itself at present only in the family, only thanks to it.

Each family has its own system of values, spiritual relations. In the family values such as integrity, philanthropy, compassion, education, diligence, responsibility and love for one's native culture, respectful attitude to the older generation should be inculcated in the family. Parents should always be interested and enjoy the successes of children in their studies, be involved in their affairs. Such family traditions as the norms of behavior transferred from the older generation to the younger ones, family holidays, and the help of older children by younger children should be peculiar.

The role of education in the life of each family has always played an important role in the formation and formation of the individual. Parents should create favorable conditions for the disclosure and development of talents and gifts, for self-determination. To convince children that only education develops in a person self-consciousness, independence, ability to creative activity, independence, personal autonomy, individuality and uniqueness, familiarity with the generally accepted norms and rules of behavior, i.e. integration into various social communities. 
Summing up, it can be noted that the family for the child is his birth and becoming. It is in the family that children receive the basics of knowledge about the world around them, with the high cultural and educational potential of their parents - continues to receive not only the basics, but the culture itself for the rest of their lives. it is in the family that the ideas about good and evil, about decency, about respectful attitude to material and spiritual values are formed. With close people in the family, children experience feelings of love, friendship, duty, responsibility, justice.

The wise teacher understands this well and successfully uses the educational process in the organization. Pedagogical skill of parents is similar to the activity of the teacher. Parents are characterized by the characteristics of the caregiver, who, in any situation of upbringing, feel ready to solve the problems that have arisen, ensuring the selection and implementation of optimal ways of solving the arising contradictions.

In conclusion, it is necessary to answer that many parents consider themselves fully prepared for education and do not consider it necessary to constantly engage in self-education in acquiring special pedagogical knowledge. Such parents should pay attention to the words of K.D. Ushinsky "The art of education," has the feature that almost all of it seem to be familiar and understandable, and some even easy - and the more understandable and easier it seems, the less a person with him sign theoretically and practically. Almost all recognize that upbringing requires patience, some think that it requires an innate ability and ability, that is, a skill, but very few have come to the conviction that apart from patience, innate ability and skill, special knowledge is needed ... "[7].

\section{References:}

1. Family is a social institution/ http://www.sparknotes.com/

2. What is the family as a social institution? http://ebrary.net/7827/sociology/ what_family_social_institution.

3. Kharchev A.G., Matskovsky M.S. Modern family and its problems. M., 1993. P.46.

4. Functions of family as a social institution. http://www.studylecturenotes.com/basicsof-sociology/functions-of-family-as-a-social-institution

5. P. Sorokin "The Man. Civilization. Society". M., 1992. P. 156-173

6. Frolov S.S. Sociology. Textbook. For higher education institutions. Moscow: Nauka, 1994, p.156. 